\title{
A Play of Significance: \\ Roy Williams's Days of Significance and the Question of Labels
}

\author{
Bénédicte Ledent
}

As soon as this project to honour Geoffrey Davis was conceived, Roy Williams's play Days of Significance (2007) imposed itself on me as an ideal piece of writing to address. Not only was Roy Williams one of Geoff's favourite playwrights, but I had actually attended a performance of this particular play with him at the London Tricycle in March 2008. Many have heard Geoff speak with typical warmth about a play or an opera that he has seen and may know to what extent his passion about performative arts is communicative. Going with him to such an event, however, is an even more memorable experience. In the case of Days of Significance, Geoff was literally brimming with enthusiasm, both before and after the show. Not that Williams's piece was in need of a champion: it proved a brilliant, provocative piece of drama, superbly supported by Maria Aberg's dynamic direction and by a cast of excellent young actors. But seeing the play with such a passionate theatre-goer as Geoff endowed it with a special quality.

Turning to the written text of this three-act play some time later was not disappointing, either, for the script of Days of Significance was as thought-provoking and compelling as the performance itself. In this essay, I would like to argue that the implications of this dramatic piece extend well beyond its most obvious subject-matter - the moral shallowness of today's British youth, on the one hand, and Britain's military involvement in Iraq, on the other. My intention, in what follows, will be to demonstrate that this play is also a play of significance, one that calls into question the notion of categorization, in particular the way in which the field of black British literature - dramatic or otherwise - is perceived and circumscribed. I will also attempt to show that through its questioning of traditional labels Days of Significance forces Britain into a critical confrontation with herself.

In an essay published in Staging New Britain, the ground-breaking collection on black and South Asian British theatre practice edited by Geoffrey Davis and Anne Fuchs, Aleks Sierz gives an overview of Roy Williams's drama and reminds us that it tackles provocative issues, among them racism, "without the usual politically correct pussyfooting or didactic 
Published in: Engaging with Literature of Commitment (vol. 2): The Worldly Scholar, ed. by Gordon Collier, Marc Delrez, Anne Fuchs \& Bénédicte Ledent (Amsterdam \& New York: Rodopi, 2012), pp. 295-307.

Status: Postprint (Author's version)

preaching," ${ }^{1}$ and that it is "characterized by a sharp opposition between two worlds." ${ }^{2}$ These features are certainly noticeable in his first play, The No Boys Cricket Club, first performed in 1996, an award-winning drama focusing on Abi, a woman in her fifties, who was in her youth "a devil with a bat." ${ }^{3}$ Now settled in England, where she has raised a family, Abi engages in a conversation with her younger self and reminisces uncompromisingly about her Caribbean past. This first play is just one example of Williams's formal inventiveness and transgressive spirit - here in relation to gender. Yet this confrontational style equally applies to the rest of his dramatic production - so far consisting of thirteen plays - where, in the words of D. Keith Peacock, "black and white English cultures, in reacting and adjusting to each other, challenge the concept of what it means to be black or white and English." ${ }^{4}$

Days of Significance is Williams's ninth published play and was first performed in 2007. It comprises three acts. The first, entitled "Much Noise," takes place "in the middle of a city centre somewhere in the south-east of England," ${ }^{5}$ and focuses on a group of immature youths for whom a nice weekend out is synonymous with binge drinking, vomiting, fighting, confronting the police, and having casual sex. Two of the boys, Ben and Jamie, are about to leave for the war front in Iraq and take advantage of their last day in England to have what they regard as a good time. Their wild night includes getting closer to two girls, Trish and her cousin Hannah, also known as "the slapper" (23). The brawls of the first act are replaced by an actual war in the second, which is set in Basra, in Iraq, and is ironically entitled "On the Side of the Angels." There, the author focuses on three British soldiers, among whom Ben, and highlights the irresponsibility of some of their actions in this conflict in which they all eventually die. "A Parting of the Ways" is the title of the third and last act, which is again set in England and concentrates on Hannah and how the war abroad has affected her life and her relationships with her friends and family.

Days of Significance was commissioned by the Royal Shakespeare Company, in the context of its Complete Works Festival, and is loosely modelled on the Bard's Much Ado

\footnotetext{
${ }^{1}$ Aleks Sierz, "'Two Worlds Fighting Each Other': Roy Williams and Contemporary Black British Theatre," in Staging New Britain: Aspects of Black and South Asian British Theatre Practice, ed. Geoffrey V. Davis \& Anne Fuchs (Brussels: Peter Lang, 2006): 182.

2 Sierz, "' Two Worlds Fighting Each Other'," 179.

${ }^{3}$ Roy Williams, Plays 1: The No Boys Cricket Club, Starstruck, Lift Off, intro. Indhu Rubasingham, foreword by Roy Williams (London: Methuen Drama, 2002): 53.

${ }^{4}$ D. Keith Peacock, "The Question of Multiculturalism: The Plays of Roy Williams," in Modern British and Irish Drama, 1800-2005, ed. Mary Luckhurst (London: Blackwell, 2006): 531.

${ }^{5}$ Roy Williams, Days of Significance (London: Methuen Drama, 2007): 5. A revised version of the play, closer to that performed at the Tricycle, was also published in Roy Williams, Plays 3: Fallout, Slow Time, Days of Significance, Absolute Beginners, intro. Roy Williams (London: Methuen Drama, 2008): 167-278. The modifications contained in this 2008 version would deserve to be investigated in depth. Although they do not
} 
Published in: Engaging with Literature of Commitment (vol. 2): The Worldly Scholar, ed. by Gordon Collier, Marc Delrez, Anne Fuchs \& Bénédicte Ledent (Amsterdam \& New York: Rodopi, 2012), pp. 295-307.

Status: Postprint (Author's version)

about Nothing, which also deals with the love lives of young people in the context of a war. The famous Shakespearean couples, Benedick and Beatrice on the one side and Claudio and Hero on the other, have become Ben and Trish and Jamie and Hannah in Williams's adaptation, which also shares with the earlier play the theme of overhearing as well as a few comic scenes involving the enforcers of law and order. Yet there are important differences, too: Shakespeare's story starts after the war and the only clashes that it shows are "skirmish[es] of wit" $^{6}$ between its carefree, aristocratic characters. By contrast, Williams's version places the war right in the middle of the narrative and presents it as a tragic rupture in the lives of his working-class protagonists. Clearly, then, his adaptation replaces the lightheartedness of Shakespeare's comedy with an unrelenting analysis of modern-day Britain, a seriousness of purpose that is obviously conveyed in Williams's chosen title. Unlike Much Ado about Nothing, then, Days of Significance marks the passage from innocence to experience, a transition crystallized in the figure of Lenny, a hamburger merchant, who is shown as the voice of adult wisdom in the first act - for example, pointing out to the young revellers that they are "nothing but fast food [themselves]" (28) - but who turns out in the third act to be a pervert of sorts who has sexual designs on his stepdaughter Hannah. ${ }^{7}$

Williams's play is full of gravity, whether he depicts the foolishness and despair of youth culture in today's Britain or conveys the meaninglessness of the war in Iraq. All of his young protagonists live in a world of physical and verbal violence where phrases such as "Shut the fuck up" (19), "I will knock yer teeth out" (43), or "I'll cave your head in" (78) are standard modes of communication. To these young people, thinking can only be boring. Their cultural references seem to be television programmes such as "Little Britain" and the "Catherine Tate Show," which incidentally are excellent analyses of the type of decadence that Williams's protagonists represent, but this dimension seems to elude them completely. Their idea of fun is peeing on their friends' shoes or throwing chips and sauce at each other. The only things that they believe in are "enormous tits" (28) or "pussy" (32). Their ambition is to get "bladdered" (9). Undoubtedly, such recklessness has at all times been characteristic of youth but the moral and intellectual emptiness of Williams's characters is truly abysmal, generating what Nicholas de Jongh has called "a world of lost inhibitions." ${ }^{8}$ What is even

\footnotetext{
change the spirit of the whole, they throw more light on the dilemmas facing the characters.

${ }^{6}$ William Shakespeare, Much Ado About Nothing, ed. Claire McEachern (Arden Shakespeare; London: Thomson Learning, 2005): 153 (I.i.59).

${ }^{7}$ Lenny is presented slightly differently in the 2008 version, where he appears to be less concupiscent and where Hannah also seems to encourage his sexual interest in her.

${ }^{8}$ Nicholas de Jongh, "Brutality and beer with the Basra boys .... Days of Significance Swan, Stratford," Evening Standard (17 January 2007): 38.
} 
Published in: Engaging with Literature of Commitment (vol. 2): The Worldly Scholar, ed. by Gordon Collier, Marc Delrez, Anne Fuchs \& Bénédicte Ledent (Amsterdam \& New York: Rodopi, 2012), pp. 295-307.

Status: Postprint (Author's version)

more worrying is that these weaknesses also inform the war that some of these youngsters wage in Iraq. When asked what they are fighting for, Ben and Jamie can only come up with the idea that "Saddam's a cunt" (32) "Cos he's got a big moustache" (33). No wonder, then, if their behaviour at the front is marked by thoughtless barbarity and an inability to distinguish right from wrong: Ben ends up "[opening] fire on a group of unarmed kids" (65) and killing one of them, while Jamie participates in the torturing of Iraqi prisoners, which he justifies by saying that he was just "following orders" (91).

The play is clearly an indictment of what the author views as "a society that allows its young to drink themselves into oblivion at weekends, then expects them to defend its moral values in a war thousands of miles away." ${ }^{9}$ This political critique, I would like to argue, has been given all the more clout because the play relies on an almost all-white cast, a choice that Roy Williams himself has explained in interviews as an expression of artistic freedom, ${ }^{10}$ but which has nonetheless surprised many commentators, if only because Williams's earlier plays, with the possible exception of Sing Yer Heart Out for the Lads (2002), focused more visibly on black characters.

Much has already been written - by Paul Gilroy and Kobena Mercer, to mention just two names - on the burden of representation that affects artists from so-called ethnic minorities. ${ }^{11}$ Such writers are often expected to depict their own community, and their interest in people from other racial groups tends to elicit reactions ranging from mere astonishment to downright hostility. This is even more likely to happen if this crossing of racial barriers is combined with a potentially explosive topic. One can recall, for example, the case of James Baldwin's Giovanni's Room, a novel first published in 1956, which not only focused exclusively on white characters but also addressed the topic of homosexuality, still taboo at the time. In the introduction to a Penguin edition of this famous text, Caryl Phillips points out the interrelatedness of these two features, writing that in Giovanni's Room "The themes of race and sexuality are unified, one feeding the other" ${ }^{12}$ and that "The uncloseting of sexual desire was to be viewed just as another step on the path towards the uncloseting of the racially prejudiced mind." 13

\footnotetext{
${ }^{9}$ Roy Williams, "Introduction" to Plays 3, x.

${ }^{10}$ See, for example, Siobhan Murphy, "Forcing the Binge Issue," Metro (11 March 2008), http://www.thislondon.co.uk/meatre/article-23451791-forcmg-the-binge-issue.do (accessed 12 March 2010).

${ }^{11}$ See Paul Gilroy, Small Acts: Thoughts on the Politics of Black Cultures (London: Serpent's Tail, 1993), and Kobena Mercer, "Black Art and the Burden of Representation," in his Welcome to the Jungle: New Positions in Black Cultural Studies (New York \& London: Routledge, 1994): 233-58.

${ }^{12}$ Caryl Phillips, "Introduction" to James Baldwin, Giovanni's Room (1956; Harmondsworth: Penguin Classics, 2001): viii.

${ }^{13}$ Phillips, "Introduction," ix.
} 
Published in: Engaging with Literature of Commitment (vol. 2): The Worldly Scholar, ed. by Gordon Collier, Marc Delrez, Anne Fuchs \& Bénédicte Ledent (Amsterdam \& New York: Rodopi, 2012), pp. 295-307.

Status: Postprint (Author's version)

Williams's audacity in Days of Significance could be read in similar fashion: i.e. his daring characterization could be linked to his thematic boldness, and viewed as a combined attempt, perhaps unconscious on the author's part, to ensure that his opinion about the state of the nation is heard and not dismissed as topically marginal, as might, regretfully, have been the case if he had only portrayed black boys being recruited for the war in Iraq. In other words, it seems that opting for a predominantly white cast might have been the best choice available to Williams to expose with any authority the moral bankruptcy of his country and thereby deconstruct the alleged superiority of some nations over others. It is interesting, in this regard, to quote a few theatre critics on the play. For example, Michael Billington made the rather paternalistic remark in the Guardian that Days of Significance "shows Williams, who has impressively charted the intricacies of Anglo-Saxon racism, widening his horizons to tackle the poisoned state of society," ${ }^{14}$ as if Williams had not done so in his other plays which proceed from the same society, or as if racism were not part and parcel of that very society. One might also reach the same conclusion after reading Paul Taylor's statement in the Independent where he comments that "Williams, whose earlier plays have been praised for their depiction of racism, here impressively extends his range." ${ }^{15}$ Similarly, one might wonder, would the Daily Mail critic Quentin Letts have been so virulent in his criticism of Roy Williams's play if its author had not been a black playwright portraying white troops? For Letts, Days of Significance indeed leaves a "bitter taste of treason," for it is an "antiwar play which depicts our squaddies as cowardly, rapacious, socially incontinent, selfish, feral losers." 16

It would surely be reductive to insist on seeing Days of Significance in terms of race, which would in addition go against Williams's legitimate aspiration towards artistic freedom. Still, I do not fully agree with Nick Curtis when he writes that Days of Significance is a play "in which race is a purely incidental issue." ${ }^{17}$ Admittedly, race is not its most visible topic gender and above all class are perhaps more obvious themes. Moreover, had Williams wanted to focus on race, he might have decided to respond to other plays by Shakespeare, such as

\footnotetext{
${ }^{14}$ Michael Billington, "Days of Significance," The Guardian (18 January 2007), http://www.guardian.co.uk/stage/2007/jan/18/theatre (accessed 14 November 2008). (My emphasis.)

${ }_{15}^{15}$ Paul Taylor, "Shakespeare Goes to War," The Independent (18 January 2008). (My emphasis.)

${ }^{16}$ Quentin Letts, "Quentin Letts First Night Review; Days of Significance by Roy Williams, Swan Theatre Stratford on Avon," Daily Mail (17 January 2007): 29. A slightly different version was published as "Soldiers' Tale Fires Blanks," Daily Mail (19 January 2007): 53.

${ }^{17}$ Nick Curtis, "Much Ado about Iraq," Evening Standard (9 January 2007), http: //www.thisislondon.co.uk/theatre/article-23381022-details/Much+ado+about+Iraq /article.do (accessed 15 November 2008).
} 
Published in: Engaging with Literature of Commitment (vol. 2): The Worldly Scholar, ed. by Gordon Collier, Marc Delrez, Anne Fuchs \& Bénédicte Ledent (Amsterdam \& New York: Rodopi, 2012), pp. 295-307.

Status: Postprint (Author's version)

Othello or The Tempest, but not Much Ado about Nothing. ${ }^{18}$ This being said, 'race' is not wholly irrelevant to Days of Significance, either. As suggested above, it might have had some impact on the play's critical reception. In addition, as one of the facets of the complexity of contemporary British society, 'race' still surfaces in the play through two black characters, who mix with the white cast but nonetheless remain slightly marginal. There is, first, Donna, Trish and Hannah's club-crawling partner, with whom they eventually fall out. Quite significantly, one of the first arguments between the girls occurs when Donna accidentally spills her drink on Hannah's top, making a "stain" (18) on it, which might very well be a suggestion of how the black presence is perceived by some people in England. In the third act, Donna is assaulted by Trish because she expresses her feelings for the latter's deceased boyfriend Ben, and is therefore accused of being "a mouthy skank bitch" (80), "skank" being an insult which may not be totally colour-blind. Nevertheless, nowhere is it fully clear whether Donna is rejected because of the colour of her skin or for other reasons independent of her complexion.

The second black character in the play is Brookes, one of the three British soldiers portrayed in the second act. His presence definitely provides more food for thought than Donna's, because his persona is more focused and richer than hers. Through him, Williams might have wanted to show that there is indeed some black in the Union Jack - to subvert Paul Gilroy's famous phrase ${ }^{19}$ - and that the British Army is one of the few public spaces in the UK where blacks and whites do actually get together, while other areas of life, like clubbing, are still relatively segregated, as suggested in the first part of the play. Yet, for all his apparent integration, Brookes proves different from his mates: he is slightly older, apparently educated. Even if he engages like them in foolish sexual banter, he does not share his fellow soldiers' arrogance towards the Arab 'Other'; unlike them, he is principled and seems to display some sense of responsibility, a fact overlooked in Lett's review of the play quoted above. After Brookes is seriously wounded, for example, he commits suicide by stabbing himself, possibly in order not to become a burden on his colleagues. Therefore, if race sets Brookes apart, so does his moral sense. In a way, he is very much like the Don Pedro of Kenneth Branagh's 1993 film adaptation of Shakespeare's Much Ado about Nothing, played by Denzel Washington, "the one person who cannot forget his responsibilities, who cannot,

\footnotetext{
${ }^{18}$ In his introduction to the play, Williams writes: "I was persuaded by my 'sister' Indhu Rubasingham not to go for the obvious, like Othello. So I chose Much Ado About Nothing" ("Introduction" to Plays 3, x).

${ }^{19}$ Paul Gilroy, "There Ain't No Black in the Union Jack": The Cultural Politics of Race and Nation (1987;

London: Routledge, 1993).
} 
Published in: Engaging with Literature of Commitment (vol. 2): The Worldly Scholar, ed. by Gordon Collier, Marc Delrez, Anne Fuchs \& Bénédicte Ledent (Amsterdam \& New York: Rodopi, 2012), pp. 295-307.

Status: Postprint (Author's version)

like the others under his charge, romp and court and play." ${ }^{20}$

Brookes is a graded soldier, a sergeant. Yet his authority is repeatedly questioned by the two privates who share his final moments and insist, for example, on calling him "boy" instead of "Sarge" (58-59). Williams's treatment of the black presence in the British Army brings to mind a television drama scripted by another black British playwright, Kwame KweiArmah, entitled "Walter's War." Taking place during the First World War, this drama is devoted to Walter Tull, a British footballer of Barbadian origin who died in action on the side of Britain in the North of France in 1918 and was the first black commissioned officer in the British Army, an unheard-of fact at the time, since "the 1914 Manual of Military Law specifically excluded 'Negroes' from exercising 'actual command' as officers." ${ }^{21}$ Tull had to face a lot of discrimination during his military service and it took until 1999 for his bravery to be officially acknowledged. Have things evolved since Tull's time in terms of the recognition of the black presence in the British Army, in spite of its increased visibility of late ${ }^{22}$ This question is indirectly raised in Days of Significance, notably through another allusion to the Great War: the fact that Brookes's name indirectly reminds us of the English poet Rupert Brooke, who like him died abroad fighting for Britain. ${ }^{23}$ Brooke's famous sonnet "The Soldier," published in 1915, might, indeed, be of some relevance to Williams's character, for it mixes patriotic sentiments with a sense of belonging to England:

If I should die, think only this of me:

That there's some corner of a foreign field

That is for ever England. There shall be

In that rich earth a richer dust concealed;

A dust whom England bore, shaped, made aware,

Gave, once, her flowers to love, her ways to roam,

A body of England's, breathing English air,

Washed by the rivers, blest by suns of home. ${ }^{24}$

\footnotetext{
${ }^{20}$ Anthony Tommasini, "The Voice Is What Counts, Not the Color of the Skin," New York Times (18 February 1998), http://www.nytimes.com/1998/02/18/theater /critic-s-notebook-the-voice-is-what-counts-not-the-color-ofthe-skin.html (accessed 18 November 2008).

${ }^{21}$ This is a quote from a web page on Walter Tull, http://web.ukonline.co.uk/ntfc/tull.htm (accessed 14 November 2008). "Walter's War" was first shown on BBC 4 on 9 November 2008.

${ }^{22}$ See Barbara Korte, "Blacks and Asians at War for Britain: Reconceptualisations in the Filmic and Literary Field?" Journal for the Study of British Cultures 14.1 (2007): 29-39.

${ }^{23}$ Note that Brookes's first name, Neil, is mentioned just once, while his fellow soldiers, Ben and Sean, are mostly referred to by their first names.

${ }^{24}$ Rupert Brooke, "The Soldier" (1915), in The Penguin Book of English Verse, ed. John Hayward
} 
Published in: Engaging with Literature of Commitment (vol. 2): The Worldly Scholar, ed. by Gordon Collier, Marc Delrez, Anne Fuchs \& Bénédicte Ledent (Amsterdam \& New York: Rodopi, 2012), pp. 295-307.

Status: Postprint (Author's version)

As these lines imply, whatever the colour of his skin, Sergeant Neil Brookes should now be regarded as fully part of England through his war sacrifice. However, there is some irony in this, if only because Brookes's conversations with his fellow soldiers indicate that his own allegiances seem to be geared more towards Arsenal football club than towards England as a nation. Once again nothing is clear-cut in Williams's dramatic universe.

Donna and Brookes apart, the other ethnic outsiders in the play are the Iraqis, who never actually enter the scene but are just voices briefly heard in the distance (65). Interestingly, the Iraqis are described by the two white soldiers as "nothing but maggots [...] [who] are not people, [...] aren't human" (58) and, even more significantly, as "sand-niggers" (57). This reification of the enemy is clearly part of the hateful othering process inherent in any war, but it might also emanate from the need of the powerful nations to have another against whom to measure their own self, especially now that people like Donna and Brookes have integrated their own ranks, whether the West likes it or not. In other words, war, which has at all times been, in Paul Gilroy's words, a "crucial process in clarifying the issue of national membership," ${ }^{25}$ might in this case be a renewed way for Europe of demonstrating its alleged superiority in the postcolonial era. This sends us back to James Baldwin, who pointed out that people "invent categories in order to feel safe. White people invented black people to give white people identity." ${ }^{26}$ If one follows this logic, Iraqis might be said to represent the new 'niggers' of a nation unsure about itself and in need of reassurance about its own worth.

In fine, however, the real underdog, the animals, in the play are the white youths themselves, most of whom are shown to be uneducated and incapable of understanding what they are doing, even if at the same time they display a form of self-assurance derived from their assumed cultural or racial supremacy over those who they consider different, hence inferior. The central characters of Days of Significance are "the type of people," Williams remarks, "that the audience may read about in the tabloids and easily dismiss." 27 The playwright, however, takes the time to explore their predicament and depicts them as finally powerless pawns in the war game of a powerful nation. He does so with compassion for what a critic has called their "vulnerability behind the bravado." ${ }^{28}$ He also displays some faith in

\footnotetext{
(Harmondsworth: Penguin, 1975): 420.

${ }^{25}$ Paul Gilroy, "The Peculiarities of the Black English," in his Small Acts, 52.

${ }^{26}$ A Dialogue: James Baldwin and Nikki Giovanni (Philadelphia PA: Lippincott, 1973): 88, quoted in Phillips, "Introduction," xi.

${ }^{27}$ Peter Lathan, "Roy Williams - Days of Significance," British Theatre Guide, http:

//www.britishtheatreguide.info/otherresources/interviews/RoyWilliams.htm (accessed 13 November 2008).

${ }^{28}$ Dominic Cavendish, "Days of Significance: A Nation's Soul," Daily Telegraph (20 March 2008),
} 
Published in: Engaging with Literature of Commitment (vol. 2): The Worldly Scholar, ed. by Gordon Collier, Marc Delrez, Anne Fuchs \& Bénédicte Ledent (Amsterdam \& New York: Rodopi, 2012), pp. 295-307.

Status: Postprint (Author's version)

the ability of education to rescue some of these young people from the prison of ignorance in which they are confined. This is the case with Hannah, who goes to college and finally "[tries] to understand" the situation (93), although her awareness is somehow bound to set her apart from her former friends, as the title of the last act indicates ("A Parting of the Ways").

As I have tried to show, Days of Significance is a play that critics will find difficult to classify, because of its intricate characterization and its sensitive subject-matter. In the last few years, commentators have repeatedly attempted to define what makes a piece of writing 'black British'. Does this label simply refer to the origins of the author? Does it, rather, apply to the content of the piece of writing in question? Is the presence of black characters a criterion? Should the subject-matter also be black, relating to transatlantic slavery, for example? All these questions somehow become superfluous with a text such as Days of Significance. For, clearly, it belongs to a new category of writing which, according to John McLeod, endeavours "to redraft an understanding of the nation and its people that is prompted by, but ultimately supersedes, exclusively Black British concerns." ${ }^{29}$ Through its complex, oblique treatment of blackness and Britishness, Days of Significance tells us that the traditional criteria can no longer be taken as defining elements of identity, literary or otherwise. If anything, the only allegiance displayed by Roy Williams in Days of Significance is to the Monsterists, a group of British playwrights, one of whose aims is to present the world as "a mucky, complex mess." ${ }^{30}$ Williams has brilliantly achieved this goal here, for, as Kathryn Prince points out, he leaves his readers and/or spectators "with a 'mucky, complex mess' of moral dilemmas about the war in Iraq, the state's duty to educate its citizens, and the nature of modern love, among others." ${ }^{31}$ Williams's refusal to categorize and simplify the world in which we live might be the ultimate legacy of this play. More than looks, more than labels, what matters is what we do. As Williams reminds us, "Never underestimate the power of your actions" $(20,25)$.

\section{WORKS CITED}

Billington, Michael. "Days of Significance," The Guardian (18 January 2007),

http://www.telegraph.co.uk/culture/theatre/drama/3671963/Days-of-Significance-A-nations-soul.html (accessed 13 November 2008).

${ }^{29}$ John McLeod, "Extra Dimensions, New Routines: Contemporary Black Writing of Britain," Wasafiri 64 (Winter 2010): 46.

${ }^{30}$ Kathryn Prince, "Days of Significance," Borrowers and Lenders: The Journal of Shakespeare and Appropriation 11.2 (Fall-Winter 2006): 6, http://www.borrowers.uga.edu/cocoon/borrowers/pdf?id=78i468 (accessed 10 March 2011).

${ }^{31}$ Prince, "Days of Significance," 6. 
Published in: Engaging with Literature of Commitment (vol. 2): The Worldly Scholar, ed. by Gordon Collier, Marc Delrez, Anne Fuchs \& Bénédicte Ledent (Amsterdam \& New York: Rodopi, 2012), pp. 295-307.

Status: Postprint (Author's version)

http://www.guardian.co.uk/stage/2007/jan/18/theatre (accessed 14 November 2008).

Brooke, Rupert. "The Soldier" (1915), in The Penguin Book of English Verse, ed. John

Hayward (Harmondsworth: Penguin, 1975): 420-21.

Cavendish, Dominic. "Days of Significance: A Nation's Soul," Daily Telegraph (20 March 2008), http://www.telegraph.co.uk/culture/theatre/drama/3671963/Days-of-

Significance-A-nations-soul.html (accessed 13 November 2008).

Curtis, Nick. "Much Ado about Iraq," Evening Standard (9 January 2007),

http://www.thisislondon.co.uk/theatre/article-23381022-

details/Much+ado+about+Iraq/article.do (accessed 15 November 2008).

de Jongh, Nicholas. "Brutality and beer with the Basra boys .... Days of Significance Swan,

Stratford," Evening Standard (17 January 2007): 38.

Gilroy, Paul. "The Peculiarities of the Black English," in his Small Acts: Thoughts on the

Politics of Black Cultures (London: Serpent's Tail, 1993): 49-62.

—. "There Ain 't No Black in the Union Jack": The Cultural Politics of Race and Nation

(1987; London: Routledge, 1993).

Giovanni, Nikki, \& James Baldwin. A Dialogue: James Baldwin and Nikki Giovanni (Philadelphia, PA: Lippincott, 1973).

Korte, Barbara. "Blacks and Asians at War for Britain: Reconceptualisations in the Filmic and Literary Field?" Journal for the Study of British Cultures 14.1 (2007): 29-39.

Lathan, Peter. "Roy Williams - Days of Significance," British Theatre Guide, http://www.britishtheatreguide.info/otherresources/interviews/RoyWilliams.htm (accessed 13 November 2008).

Letts, Quentin. "Quentin Letts First Night Review; Days of Significance by Roy Williams,

Swan Theatre Stratford on Avon," Daily Mail (17 January 2007): 29. A slightly

different version was published as "Soldiers' Tale Fires Blanks," Daily Mail (19 January 2007): 53.

McLeod, John. "Extra Dimensions, New Routines: Contemporary Black Writing of Britain," Wasafiri 64 (Winter 2010): 45-52.

Mercer, Kobena. "Black Art and the Burden of Representation," in Mercer, Welcome to the Jungle: New Positions in Black Cultural Studies (New York \& London: Routledge, 1994): 233-58.

Much Ado about Nothing, dir. Kenneth Branagh, 1993.

Murphy, Siobhan. "Forcing the Binge Issue," Metro (11 March 2008), 
Published in: Engaging with Literature of Commitment (vol. 2): The Worldly Scholar, ed. by Gordon Collier, Marc Delrez, Anne Fuchs \& Bénédicte Ledent (Amsterdam \& New York: Rodopi, 2012), pp. 295-307.

Status: Postprint (Author's version)

http://www.thisislondon.co.uk/theatre/article-23451791-

details/Forcing+the+binge+issue/article.do (accessed 14 November 2008).

Peacock, D. Keith. "The Question of Multiculturalism: The Plays of Roy Williams," in Modern British and Irish Drama, 1800-2005, ed. Mary Luckhurst (London: Blackwell, 2006): 530-40.

Phillips, Caryl. "Introduction" to James Baldwin, Giovanni's Room (1956; London: Penguin Classics, 2001): v-xi.

Prince, Kathryn. "Days of Significance," Borrowers and Lenders: The Journal of Shakespeare and Appropriation 11.2 (Fall-Winter 2006): 2-6, http://bandl.english.uga.edu/cocoon/borrowers/request?id=78i468 (accessed 14 November 2008).

Shakespeare, William. Much Ado About Nothing, ed. Claire McEachern (Arden Shakespeare; London: Thomson Learning, 2005).

Sierz, Aleks. "'Two Worlds Fighting Each Other': Roy Williams and Contemporary Black British Theatre," in Staging New Britain: Aspects of Black and South Asian British Theatre Practice, ed. Geoffrey V. Davis \& Anne Fuchs (Brussels: Peter Lang, 2006): 177-88.

Taylor, Paul. "Shakespeare Goes to War," The Independent (18 January 2008).

Tommasini, Anthony. "The Voice Is What Counts, Not the Color of the Skin," New York Times (18 February, 1998), http://www.nytimes.com/1998/02/18/theater/critic-snotebook-the-voice-is-what-counts-not-the-color-of-the-skin.html (accessed 18 November 2008).

"Walter's War," dir. Alrick Riley, BBC drama, 2008.

Williams, Roy. Days of Significance (London: Methuen Drama, 2007). Also published in a revised version in Plays 3: Fallout, Slow Time, Days of Significance, Absolute Beginners, intro. Roy Williams (London: Methuen Drama, 2008): 167-278.

—. "Introduction" to Williams, Plays 3, viii-X.

—. Plays 1: The No Boys Cricket Club, Starstruck, Lift Off, intro. Indhu Rubasingham, foreword by Roy Williams (London: Methuen Drama, 2002). 